răng cửa nhỏ hơn giới hạn bình thường cho thấy vẩu răng cửa hai hàm. Độ cắn chìa lớn.

\section{TÀI LIÊU THAM KHẢO}

1. Park IC, Bowman D, Klapper L. A cephalometric study of Korean adults. Am J Orthod Dentofacial Orthop. 1989;96(1):54-59. doi:10.1016/08895406(89)90229-1

2. Lim H-J, Ko K-T, Hwang H-S. Esthetic impact of premolar extraction and nonextraction treatments on Korean borderline patients. American Journal of Orthodontics and Dentofacial Orthopedics. 2008;133(4):524-531.

3. Guo $Y$, Han $X, X u H$, Ai $D$, Zeng $H$, Bai $D$. Morphological characteristics influencing the orthodontic extraction strategies for Angle's class II division 1 malocclusions. Progress in orthodontics. 2014;15(1):1-7.

4. Kuroda S, Yamada K, Deguchi T, Kyung H-M, Takano-Yamamoto $\mathbf{T}$. Class II malocclusion treated with miniscrew anchorage: comparison with traditional orthodontic mechanics outcomes.
American journal of orthodontics and dentofacial orthopedics. 2009;135(3):302-309.

5. Sivakumar $A$, Nalabothu $P$, Thanh HN, Antonarakis GS. A Comparison of Craniofacial Characteristics between Two Different Adult Populations with Class II Malocclusion-A CrossSectional Retrospective Study. Biology (Basel). 2021;10(5):438. doi:10.3390/biology10050438

6. Fushima $K$, Kitamura $Y$, Mita $H$, et al. Significance of the cant of the posterior occlusal plane in Class II division I malocclusions. The European Journal of Orthodontics. 1996;18(1):27-40.

7. Staley RN, Stuntz WR, Peterson LC. A comparison of arch widths in adults with normal occlusion and adults with Class II, Division 1 malocclusion. American journal of orthodontics. 1985;88(2):163-169.

8. Pancherz $\mathbf{H}$, Zieber $K$, Hoyer B. Cephalometric characteristics of Class II division 1 and Class II division 2 malocclusions: a comparative study in children. The Angle Orthodontist. 1997;67(2):111-120.

\title{
VIÊM MŨI XOANG DO NẤM XÂM LẤN CẤP TÍNH Ở BÊNNH NHÂN ĐÁI THÁO ĐƯỜNG
}

\section{TÓM TẮT}

Viêm mũi xoang do nấm có nhiều thể lâm sàng khác nhau ${ }_{L}$ trong đó thể nấm xâm lấn cấp tính hiếm gặp nên dễ chấn đoán nhầm với các bênh lý ác tính. Ca lâm sàng: bệnh nhân nữ 68 tuổi, tiền sử đái tháo đường có biểu hiện sốt và đau nhức vùng xoang hàm trái. Chẩn đoán ban đầu là viêm xoang cấp có bội nhiễm nấm Aspergillus và được phẫu thuật nội soi mũ̃i xoang. Sau phẫu thuật bệnh nhân được dùng kháng sinh liều cao và uống thuốc chống nấm, tuy nhiên bệnh tiến triển xấu hơn, xuất hiện liệt các dây thần kinh so và đau đầu dữ dội, Chẩn đoán hình ảnh nghi ngờ $\mathrm{K}$ vòm, tuy nhiên sau đó khẳng định chẩn đoán Viêm xoang do nấm xâm lấn cấp tính qua bấm sinh thiết vòm. Mặc dù đã dùng Amphotericin $B$ nhưng bênh nhân vấn tử vong do nấm xâm lấn nền so và giảm bạch cầu do ức chế tủy xương. Kết luận: Nắm vững các triêu chứng, dấu hiệu lâm sàng và tiêu chuẩn chẩn đoán giúp cho các nhà lâm sàng chẩn đoán nhanh chóng và điêu trị kịp thời, giảm tỉ lệ tử vong đáng kế.

Tư khóa: viêm mũi xoang, Aspergillus, cấp tính, xâm lấn, đái đường.

*Trường Đai hoc Y Dược, ĐHQG Hà Nội,

**Bênh viện Hữu Nghi đa khoa Nghê An

Chịu trách nhiệm chính: Đoàn Thị Hồng Hoa

Email: dhhoa63@yahoo.fr

Ngày nhân bài: 22.6.2021

Ngày phản biên khoa hoc: 20.8.2021

Ngày duyệt bải: 27.8 .2021

\section{Đoàn Thị Hồng Hoa*, Chu Thị Kim Anh**, Nguyễn Như Đua*, Nguyễn Lê Hoa*}

\section{SUMMARY}

\section{ACUTE INVASIVE FUNGAL SINUSITIS IN}

PATIENTS WITH DIABETES MELLITUS

Fungal rhinosinusitis has many different clinical forms, in which acute invasive fungal form is rare, so it is easy to misdiagnose with malignancies. Clinical case: A 68-year-old female patient with a history of diabetes presents with fever and pain in the left maxillary sinus. Initial diagnosis was acute sinusitis with Aspergillus superinfection and endoscopic sinus surgery. After surgery, the patient was given high-dose antibiotics and anti-fungal drugs, but the disease progressed worse, appeared symptoms of cranial nerve paralysis and severe headache. Imaging tests suspected nasopharyngeal cancer, but the final diagnosis was acute invasive fungal sinusitis by nasopharyngeal biopsy. Despite taking Amphotericin B, the patient still died from fungi invading the skull base and leukopenia due to bone marrow suppression. Conclusion: Mastering the symptoms, clinical signs and diagnostic criteria helps clinicians make a quick diagnosis and timely treatment, significantly reducing mortality.

Keywords. rhinosinusitis, Aspergillus, acute, invasive, diabetes.

\section{I. ĐĂT VẤN ĐỀ}

Viêm mũi xoang do nấm có xu hướng gia tăng trong những năm gần đây cùng với sự đô thị hóa, ô nhiếm môi trường và sự gia tăng của các bệnh nhân suy giảm miền dịch như đái tháo 
đường, những bênh nhân phải điều trị hóa chất hay thuốc ức chể miễn dịch. Có 2 loại nấm chính gây viêm mũi xoang đó là Aspergillus và Mucoracea, chúng đều là thực vật hoại sinh tìm thấy trong đất và bui ở trên toàn thế giới. Chính vì vậy, tùy theo hệ thống miễn dịch của mỗi cá thể nên có nhiều thể lâm sàng khác nhau. Phần lớn gặp các thể viêm mũi xoang không xâm lấn bao gồm nấm mũi xoang bề mặt, viêm mũi xoang dị ứng do nấm và nhiễm nấm cầu. Tuy nhiên, ở những người suy giảm miễn dịch, nấm này có thể xâm lấn vào mạch máu, gây tắc mạch và thiếu máu niêm mạc mũi. Từ đó có thể xâm lấn phá hủy xương và tổ chức xung quanh đặc biệt là tổn thương hốc mắt và nội sọ và đôi khi lan đến các cơ quan khác của cở thể. Các triêuu chứng lâm sàng và các dữ liệu về chẩn đoán hình ảnh đôi khi giống như u ác tính hay bệnh u hạt. Cần phải làm xét nghiệm mô bệnh học để chẩn đoán chính xác và lựa chon điều trị thích hợp cho viêm mũi xoang xâm lấn do nấm. Tuy nhiên chẩn đoán có thể gặp nhiều khó khăn ngay cả khi có kết quả mô bệnh học. Trong báo cáo này, chúng tôi mô tả một trường hợp nấm mũi xoang xâm lấn tối cấp ở bệnh nhân đái tháo đường có lan tràn vào nền sọ biểu hiện tương tự như ung thư vòm họng trên chấn đoán hình ảnh.

\section{CA LÂM SÀNG}

Bệnh nhân nữ 68 tuổi có tiền sử đái tháo đường typs II được chuyển đến vì liệt mặt và sụp mi xuất hiện sau phẫu thuật mũi xoang 1 tuần với chẩn đoán viêm mũi xoang do nấm aspergillus. Khởi đầu bệnh nhân bị sốt đau nhức vùng xoang hàm trái lan ra $1 / 2$ đầu kèm theo chảy mũi mủ. Bệnh nhân đã được chẩn đoán là viêm mũi xoang cấp và dùng kháng sinh nhóm quinolon (Tavanic) 1 tuần, bệnh nhân đõ sốt và đau nhức. Sau đó, bênh nhân được tiến hành phẫu thuật nội soi mũi xoang bên trái, phát hiện cuốn dưới niểm mạc nhợt mủn nát, hoại tử một phần và thành bên mũi bị phá hủy, trong lòng xoang hàm đầy mủ đặc trẳng với nhiều tổ chức lổn nhổn màu xám. Bệnh phẩm được lấy làm giải phẫu bệnh. Phẫu thuật viên đã tiến hành nạo vét cả xoang sàng, trán, bướm bên trái và bơm rửa hốc mổ bằng betadin. Sau 3 ngày, kết quả giải phẫu bệnh là tổn thương viêm loét kèm nhiếm nấm Aspergillus. Bệnh nhân được điều trị bằng kháng sinh Fortum tiêm tĩnh mạch kèm Itraconazol $200 \mathrm{mg} \mathrm{x} 2$ viên/ngày và rửa mũi hàng ngày. Tuy nhiên bệnh nhân vẫn đau nhức $1 / 2$ mặt đặc biệt hốc mắt, đến ngày thứ 7 sau mổ bệnh nhẩn xuất hiện liệt mặt, sụp mi. Bệnh nhân được chụp cắt lớp sọ não : thây có hình ảnh viêm đa xoang và nhồi máu ổ khuyết, teo não tuổi già nên được chuyển sang viện lão khoa. Tại đây bệnh nhân được truyền Rocephin, Metronidazol, và thuốc tăng cường mạch máu não nhưng tình trạng bệnh nhân xấu hơn, đau đầu nhiều, ăn uống kém, không đi lại được. Tại đây, bệnh nhân được chụp cộng hưởng từ phát hiện thây tổn thương vùng vòm trái kích thước $36 \times 27$ mm, tăng tín hiệu trên T2W, FLAIR đồng tín hiệu trên T1W trước tiêm, ngấm thuốc mạnh sau tiêm, tổn thương thâm nhiễm rộng xung quanh vùng vòm, thâm nhiễm hầu họng hố cơ cắn, xương bướm bên trái, gây tắc vòi nhĩ và ứ dịch tai giữa trái nghi ngờ $\mathrm{K}$ vòm. Bênh nhân được chuyển sang khoa hồi sức.

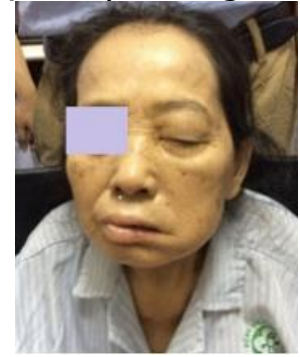

Hình 1. Bệnh nhân sau mồ xoang 2 tuân: liệt măt, sụp mi và lồi măt trái

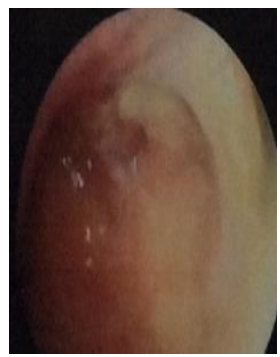

Hình 2. Nọi soi trần vòm trái nề nhơt mâu, dâu hiệu hoại tử nền so
Khám lúc vào khoa hồi sức, bệnh nhân tỉnh, nhợt nhạt, không đi lại được, không sốt, đau nhức hốc mắt trái, liệt mặt trái hoàn toàn, sụp mi, lồi mắt trái. Nội soi hốc mũi có nhiều vẩy máu trong hốc mũi trái. cuốn mũi dưới trái đã bị cắt, khe giữa và ngách bướm sàng, niêm mạc nề dày có nhiều giả mạc dễ chảy máu. Vòm mũi họng niêm mạc viêm nề nhợt màu. Công thức máu thấy tình trạng thiếu máu hồng cầu dao động 3.20 đến $2.55 \mathrm{~T} / \mathrm{L}$, HCT 0,28 - 0,23 L/L, Bạch cầu $5,9-3,42 \mathrm{G} / \mathrm{L}$, tiểu cầu $142-179 \mathrm{G} / \mathrm{L}$, đường huyết dao động 9,8-12,2 mmol/L, tình trạng protein toàn phần và albumin đều giảm, creatinin 35-37 umol/L. Chụp cộng hưởng từ lần 2 thây hình ảnh tổn thương vòm bên trái không rõ bờ và ranh giới, thâm nhiễm tổ chức xung quanh dọc theo vòi nhĩ, lan vào ống động mạch cảnh trong trái và thâm nhiễm cả vào khoang cơ cắn phía trước. Bệnh nhân được hội chẩn liên chuyên khoa với chẩn đoán cốt tủy viêm nền sọ nghi do nấm chưa loại trừ $K$ vòm. Tiến hành sinh thiết ở 2 vị trí ngách bướm, nẹp sau loa vòi trái và ngách bướm sàng trái, thấy nhiều vùng hoai tử và xâm nhập nhiêu bạch cầu ái toan, lấn trong tổ chức hoại tử có nhiều hình ảnh nấm 
Aspergilus, không có tế bào ác tính. Bệnh nhân đã được điêu trị bằng Amphotericin $\mathrm{B}$ bằng đường tĩnh mạch nhưng toàn trạng diễn biến xấu và thiếu máu nặng mặc dù được truyền máu, rồi hôn mê và tử vong sau 10 ngày điều trị.
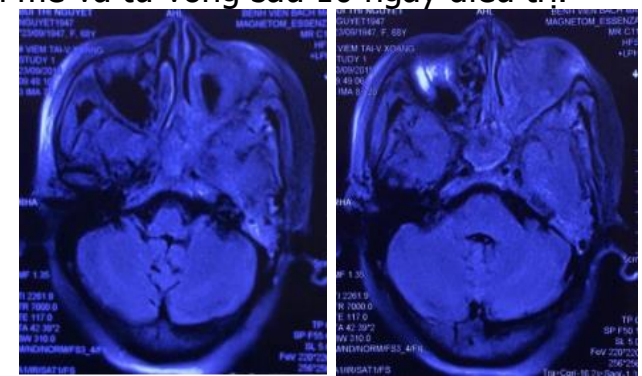

Hình 3: Mất độ tăng tương phản nền sọ trên MRI có tiêm thuốc cản quang kèm xâm lấn đỉnh hốc mắt.

\section{BÀN LUÂ̂N}

Viêm mũi xoang do nấm chiếm khoảng 5$50 \%$ các trưởng hợp đặc biệt là viêm mũi xoang mạn không thuyên giảm. Có nhiều thể lâm sàng, vì vậy bệnh lý này thường dễ bị chẩn đoán nhầm. Nó có thể có triệu chứng hoặc không triêu chứng cũng như là cấp tính hay mạn tính. Nhiếm nấm mũi xoang cần được nhận biết để tránh tỉ lệ tử vong đáng kể. Trong trường hợp viêm mũi xoang mủ không đáp ứng với trên 2 đợt kháng sinh và các dữ liệu điện quang phải nghi ngờ nấm xoang. Các yếu tố thúc đẩy nhiểm nấm trong các xoang là polyp, ứ đọng dịch tiết với các yếu tố khác như giảm bạch cầu, sử dụng kháng sinh không hợp lý, các thuốc ức chế miển dịch, corticoid, đái tháo đường không kiểm soát, HIV, chấn thương, tia xạ (1). Tuy nhiên, trong một số trường hợp cần phải phân biệt ngay nấm xâm lấn và nấm không xâm lấn vì chẩn đoán và điều trị sớm là chìa khóa thành công. Chẩn đoán nấm mũi xoang xâm lấn cấp tính trước tiên dựa vào lâm sàng, ngoài ra các dữ liệu hình ảnh và mô bệnh học là minh chứng của viêm mũi xoang xẩm lấn cấp tính này.

Tiêu chuẩn chẩn đoán nấm xâm lấn hiện nay chưa thống nhất, nhưng phần lớn các tác giả vẫn đồng thuận theo cách phân chia của deShazo năm 1997 (2). Tác giả đã đưa ra tiêu chuẩn của chẩn đoán viêm mũi xoang xâm lấn gồm:

- Dày niêm mạc hay mức nước hới tương ứng với xoang viêm trên hình ảnh $X$ quang.

- Có bằng chứng về mô bệnh học về các dạng sợi nấm trong niêm mạc, dưới niêm mạc, các mạch máu hay xương của xoang.

- Đề chẩn đoán viêm xoang do nấm xâm lấn nụ hạt, bằng chứng về mô bệnh học của các dạng sợi nấm trong niêm mạc, dưới niêm mạc, các mạch máu hay xương của xoang phối hợp với nụ hạt chứa các tế bào không lồ, và phải âm tính đối với mycobacteria.

- Biểu hiện lâm sàng thường gặp nhất của nấm xoang cấp tính là đau đầu, cương tụ hốc mũi, sốt, đau mă̆t và đau quanh hốc mắt. Khi nghi ngờ, nội soi mũi xoang là cơ bản để đánh giá dấu hiệu tổn thương nấm. Niêm mạc nhợt, loét và nụ hạt chiếm trên $75 \%$ các trưởng hợp (3). Các dấu hiệu khác như thiếu máu cục bộ hay hoại tử tổ chức quan sát thấy trong trường hợp nấm xoang xâm lấn nặng hơn. Sinh thiết cuốn giữa được đề xuất để chẩn đoán trước khi bệnh rõ ràng $(1,4)$. Gợi ý này dựa trên quan sát thấy cuốn giữa là vị trí nấm xâm nhập phổ biến nhất trong hốc mũi ở bệnh nhân nấm xoang xâm lấn cấp.

- Về chẩn đoán hình ảnh, độ nhạy của CT Scanner còn hạn chế trong chẩn đoán giai đoạn đầu. Ăn mòn xương là dấu hiệu rõ ràng nhưng thường gặp ở giai đoạn muộn. Một số dấu hiệu khác được gợi ý nấm xâm lấn cấp tính là tổn thương một bên, thâm nhiễm mõ quanh xoang và phù nề niêm mạc nặng. Ngày nay, người ta đã chỉ ra rằng các thông tin về chụp cộng hưởng từ có tiêm thuốc cản quang có thể hữu ích trong chẩn đoán tiên lượng (6). Mất độ tăng tương phản trên chụp cộng hưởng từ biểu hiện nhồi máu tổ chức thứ phát do nấm xâm nhập vào mạch máu, nên các thuốc chống nấm không thể thẩm nhiếm vào và đòi hỏi phẩu thuật cắt bỏ. Tuy nhiên, phẫu thuật viên có thể do dự khi lấy bỏ tổn thương ngoài mũi xoang nếu có tổn thương ở vị trí mà khi lấy bỏ, có khả năng gây các biến chứng nguy hiểm sau mổ như rò dịch não tủy và tổn thương mạch máu lớn. Do vậy, phân tích mối liên quan giữa vị trí tổn thương cụ thể ở vùng ngoài mũi xoang và tỉ lệ tổ chức sống sót là rất quan trọng trong việc dự đoán tiên lượng của bệnh nhân. Các nghiên cứu gần đây đã xác nhận rằng mất độ tăng tương phản ngoài vùng mũi xoang phản ánh tổn thương hoại tử, đặc biệt ở nền sọ, là một yếu tố tiên lượng xấu. Trển lâm sàng, khi viêm mũi xoang do nấm xâm lấn cấp tính được chản đoán, điều trị nội khoa và phẫu thuật phải được nhanh chóng, kịp thời. Thuốc chống nấm được sử dụng nhiêu nhất là $A m p h o t e r i c i n ~ B$ và ngày nay là Voricorazole. Theo hướng dẫn điều trị của hiệp hội bệnh Hoa Kỳ năm 2008 đối với bệnh Aspergillus xâm lấn, Voricorazole ( phổ rộng triazol) là thuốc lựa chọn cho điều trị bệnh Aspergillus xâm lấn vì khả năng dung nạp tốt hơn, tăng hiệu quả, cải thiện tỉ lệ sống và giảm độc tính hơn so với Amphotericin $B(7,8)$. 
Đồng thời tiến hành cắt bỏ các tổ chức hoai tử là quan trọng ở bệnh nhân nấm xâm lấn này vì việc loại bỏ các tổ chức bị tàn phá làm tăng khă năng thuốc chống nấm tiếp cân các khu vực bị nhiễm bệnh, làn giảm gách nặng về nấm và làm chậm sự tiến triển của bệnh. Ngoài ra, tác động này không chỉ tại chỗ mà từ đó làm giảm cắng thẳng đối với sự tăng bạch cầu trung tính, tạo điều kiện phục hồi tủy xương.

Ở bệnh nhân của chúng tôi, phân tích các triệu chứng lâm sàng và cận lâm sàng khẳng định chẩn đoán viêm mũi xoang do Aspergillus xâm lấn tối cấp ở bệnh nhân đái tháo đường mặc dù có kết quả về chẩn đoán hình ảnh nghi ngờ $K$ vòm. Bệnh nhân tử vong do bệnh tiến triển xâm lấn vào nền so và hốc mắt với rối loạn sinh tủy gây giảm cả ba dòng tế bào. Bằng chứng trên lâm sàng, bênh tiến triển cấp tính với đau nhức vùng mặt trái, sốt khởi đâu, sau 1 tuần phẫu thuật đã thẩy cuốn dưới và thành bên hốc mũi hoại tử, khi làm xét nghiện mô học có nấm Aspergillus. Sau khi điều trị như viêm xoang cấp có bội nhiễm nấm, bệnh tiến triển xâm lấn vào nền sọ biểu hiện trần vòm trái niêm mac nhớt, sinh thiết có tổn thương viêm hoại tử với nhiếm nấm Aspergillus. Trên chẩn đoán hình ảnh với chụp cộng hưởng từ có tiêm thuốc cản quang, xuất hiện dấu hiệu điển hình mất độ tăng tương phản biểu hiện hoại tử ở vùng cánh bướm lớn bên trái, thân bướm, hố dưới xương thái dương trái mà kết quả chỉ rõ hình ảnh tổ chức bất thường vùng nền sọ không rõ bờ và ranh giới. Tổ chức viêm mềm được xác định trong xoang bướm, đỉnh hốc mắt trái, xoang hang trái với hep động mach cảnh trong và thâm nhiễm vào khoang cơ cắn trước. Bệnh nhân tử vong vì cốt tủy viêm nền so do nấm xâm lấn kèm rối loạn sinh tủy với giảm thiểu cả 3 dòng. Đây là bệnh lý hiếm gặp, phẫu thuật viên đầu tiên khi tiếp nhân bệnh nhân đã nghĩ đến nấm xoang cấp ở bệnh nhân đái tháo đường, đã tiến hành phẫu thuật lấy bỏ tổ chức hoại tử ở mũi xoang và sử dụng thuốc nấm Itraconazol như trong viêm mũi xoang thể không xâm lấn. Tiến triển vào nền sọ nhanh chóng, chỉ sau 1 tuần đã có tổn thương hốc mắt và liêt các dây thần kinh so. Mặc dù đã chẩn đoán được loại nấm khi sinh thiết tổ chức, nhưng nhà giải phẫu bệnh thường kết luận: trong tổ chức hoại tử có nhiều hình ảnh nấm Aspergilus, không có tế bào ác tính, không ghi rõ mức độ xâm nhập qua niêm mạc hay xương để hướng các nhà lầm sàng nghĩ đển nấm xâm lấn.

Tóm lại, cần chẩn đoán và điều trị sớm nấm xâm lấn để giảm thiểu tỉ lệ tử vong. Ở những bệnh nhân suy giảm miễn dịch xuất hiện các triệu chứng viêm mũi xoang cấp bất thường như đau đầu, sốt... không đáp ứng với kháng sinh phổ rông với tổn thương viêm nhợt màu phải nghĩ đến nấm xâm lấn. Sinh thiết kèm theo các thông tin về hình ảnh giúp khẳng định chẩn đoán.

\section{KẾT LUẬN}

Cần câp nhật các thể lâm sàng của nấm mũi xoang để phát hiên và điều tri sớm, đăc biệt là thể nấm xâm lấn cấp tính. Ngoài triệu chứng như viêm xoang cấp, kèm niêm mạc nhợt màu hay vảy đen ở cuốn giữa, khe giữa, cuốn dưới với dấu hiệu mất độ tăng tương phản trên phim chụp MRI có tiêm thuốc cản quang ở bệnh nhân suy giảm miễn dịch là dấu hiệu gợi ý. Sinh thiết sớm để đưa ra chẩn đoán. Điều trị nội khoa bằng Voricorazole và phẫu thuật lấy bỏ tổ chức hoại tử là cách thức lựa chọn điều trị cho nấm cấp tính mũi xoang hiện nay.

\section{TÀI LIÊU THAM KHẢO}

1. Singh N, Siddaraju N, Kumar S, Muniraj F, Bakshi S, Gopalakrishnan $\mathbf{S}$. Fine-needle aspiration biopsy as an initial diagnostic modality in a clinically unsuspected case of invasive maxillary fungal sinusitis. A case report. Diagn Cytopathol. 2010; 38:220-3

2. Richard D. deShazo, Margaret O'Brien, Kimberle Chapin, Maria Soto-Aguilar, Lloyd Gardner, Ronnie Swain. A New Classification and Diagnostic Criteria for Invasive Fungal Sinusitis. Arch Otolaryngol Head Neck Surg. 1997; 123:1181-1188.

3. Sharma RR and Sharma A. Paranasal Invasive Fungal Sinusitis and its Central Nervous System Complications: Current Understanding and their Management. Austin J Otolaryngol.2016: 3 (2) : 1077.

4. Fabiana C.P.Valera, Tassiana de Lago, Edwin Tamashiro, Camila Carrara Yassuda, Flavia Silveira, Wilma T. Anselmo- Lima. Prognosis of acute invasive fungal shinosinusitis related to underlying disease. International Journal of Infectious Diseases 15 ( 2011) e 841-e844.

5. Turner, J. H., Soudry, E., Nayak, J. V. \& Hwang, P. H. Survival outcomes in acute invasive fungal sinusitis: a systematic review and quantitative synthesis of published evidence. Laryngoscope. 123, 1112-1118 (2013).

6. Seo, J. et al. Cervicofacial tissue infarction in patients with acute invasive fungal sinusitis: prevalence and characteristic MR imaging findings. Neuroradiology. 55, 467-473 (2013).

7. Fernandez, I. J. et al. Acute Invasive Fungal Rhinosinusitis in immunocompromised Patients: Role of an Early Diagnosis. Otolaryngol. Head. Neck Surg. 159, 386-393 (2018).

8. Beatriz Paral- Cagigal, Luis-Miguel RedondoGonzalez, Alberto Verrier- Hernandez. Invasive maxillary sinus aspergillosis: A case report successfully treated with voriconazole and surgical debridement. J Clin Exp Dent. 2014; 6 (4) e 448-51. 